Research Article

Human and Medical Genetics

\title{
Hypermethylation status of DAPK, MGMT and RUNX3 in HPV negative oral and oropharyngeal squamous cell carcinoma
}

Raquel Silva dos Reis ${ }^{1}$, Jéssica Aflávio dos Santos ${ }^{1}$, Priscila Marinho de Abreu ${ }^{2,3}$, Raquel Spinassé Dettogni ${ }^{1}$, Eldamária de Vargas Wolfgramm dos Santos ${ }^{1}$ iD, Elaine Stur ${ }^{1}$, Lidiane Pignaton Agostini ${ }^{1}$, Quézia Silva Anders ${ }^{4}$, Lyvia Neves Rebello Alves ${ }^{1,2}$, Isabella Bittencourt do Valle ${ }^{2,3}$, Marília Arantes Lima ${ }^{3}$, Evandro Duccini Souza ${ }^{5}$, José Roberto Vasconcelos de Podestá ${ }^{5}$, Sandra Ventorin von Zeidler ${ }^{2,3}$, Melissa de Freitas Cordeiro-Silva ${ }^{1}$ and Iúri Drumond Louro ${ }^{1,2}$

${ }^{1}$ Universidade Federal do Espírito Santo, Departamento de Ciências Biológicas, Núcleo de Genética Humana e Molecular, Vitória, ES, Brazil.

${ }^{2}$ Universidade Federal do Espírito Santo, Programa de Pós-Graduação em Biotecnologia, Vitória, ES, Brazil.

${ }^{3}$ Universidade Federal do Espírito Santo, Departamento de Patologia, Laboratório de Patologia Molecular, Vitória, ES, Brazil.

${ }^{4}$ Universidade Federal do Espírito Santo, Programa de Pós-Graduação em Ciências Fisiológicas, Vitória, ES, Brazil.

${ }^{5}$ Hospital Santa Rita de Cássia - SESA, Programa de Prevenção e Detecção Precoce do Câncer Bucal, Setor de Cirurgia de Cabeça e Pescoço, Vitória, ES, Brazil.

\begin{abstract}
Squamous cell carcinoma of the oral cavity and oropharynx is the sixth most common type of cancer in the world. During tumorigenesis, gene promoter hypermethylation is considered an important mechanism of transcription silencing of tumor suppressor genes, such as DAPK, MGMT and RUNX3. These genes participate in signaling pathways related to apoptosis, DNA repair and proliferation whose loss of expression is possibly associated with cancer development and progression. In order to investigate associations between hypermethylation and clinicopathological and prognostic parameters, promoter methylation was evaluated in $72 \mathrm{HPV}$ negative oral and oropharyngeal tumors using methylation-specific PCR. Hypermethylation frequencies found for DAPK, MGMT and RUNX3 were $38.88 \%, 19.44 \%$ and $1.38 \%$ respectively. Patients with MGMT hypermethylation had a better 2-year overall survival compared to patients without methylation. Being MGMT a repair gene for alkylating agents, it could be a biomarker of treatment response for patients who are candidates for cisplatin chemotherapy, predicting drug resistance. In view of the considerable levels of hypermethylation in cancer cells and, for MGMT, its prognostic relevance, DAPK and MGMT show potential as epigenetic markers, in a way that additional studies may test its viability and efficacy in clinical management.
\end{abstract}

Keywords: tumor suppressor genes, methylation, HPV negative tumors, squamous cell carcinoma.

Received: October 10, 2019; Accepted: June 03, 2020.

\section{Introduction}

Head and neck squamous cell carcinoma (HNSCC) is a heterogeneous group of epithelial tumors that describe approximately $90 \%$ of the malignant neoplasms occurring in the oral cavity, oropharynx, hypopharynx and larynx (Pai and Westra, 2009; Hussein et al., 2017). Oral and oro-

Send correspondence to Eldamária de Vargas Wolfgramm dos Santos. Universidade Federal do Espírito Santo, Departamento de Ciências Biológicas, Núcleo de Genética Humana e Molecular, Avenida Fernando Ferrari, 514, Goiabeiras, 29075-910, Vitória, ES, Brazil. E-mail: eldamariavw@yahoo.com.br. pharyngeal squamous cell carcinoma (OOSCC) have a global estimate of 300,373 and 142,387 new cases per year, respectively (Gupta et al., 2016), being together the sixth most common cancer in the world (Morandi et al., 2017).

A common etiological factor in HNSCC is prolonged and excessive alcohol and tobacco consumption which establish a synergistic, dose-dependent relationship between them (Polanska et al., 2014). The infection by high-risk Human papillomavirus (HPV) has been particularly associated with oropharyngeal cancer (Lechner et al., 2013; D'Souza and Saranath, 2015; Sailer et al., 2017). HPV positive and HPV negative tumors have a distinct molecular profile, even 
in tumors with similar clinical parameters, leading to different prognostic expectations (Colacino et al., 2013; Lechner et al., 2013; Erhart et al., 2016; Sailer et al., 2017).

The OOSCC are very aggressive in their biologic behavior and result in a deforming and destructive disease, with frequent early lymph node metastases and potential for distant metastases over time - even after adequate local therapy (Miyazaki et al., 2006; Byakodi et al., 2012). These factors cause a significant worse prognosis and higher radio and chemotherapy morbidity (Morandi et al., 2017). Mortality rates have remained unchanged (50\% within five years after diagnosis) over the past 30 years (Morandi et al., 2017) and survival rate of HNSCC is lower when compared to other cancers like breast, cervix and colorectal (Jemal et al., 2008a, 2008b). Factors that contribute for this scenario are the failure in early diagnosis (two thirds are diagnosed in III-IV stages) and the lack of molecular markers that indicate tumor behavior and allow patient stratification for more personalized therapy (Mao et al., 2004; Montebugnoli et al., 2014; Morandi et al., 2017).

Therefore, diagnoses in early stages and rigorous follow-up care have a significant effect on survival and outcome (Shield et al., 2017). Currently, TNM staging system is the main parameter used for treatment decision and prognosis (Hermanek et al., 1997). However, tumors with identical staging at same anatomical site can present distinct behavior (Pai and Westra, 2009). In this context, molecular markers for cancer detection and prognosis should be explored with the intent to improve screening accuracy (Pai and Westra, 2009; Carvalho et al., 2011; Dahiya and Dhankhar, 2016).

DNA hypermethylation may be a suitable biomarker of tumor progression by allowing the prospection of malignant lesions and survival and prognostic associations (Taioli et al., 2009; Koutsimpelas et al., 2012; Castilho et al., 2017). This molecular alteration consists of transcriptional silencing of promoter regions in tumor suppressor genes (TSGs) (Carvalho et al., 2011; Castilho et al., 2017).

$\mathrm{CpG}$ island hypermethylation in promoter region of TGSs as death-associated protein kinase (DAPK), $O^{6}$-methylguanine DNA methyltransferase (MGMT) and runt-related transcription factor 3 (RUNX3) have been consistently observed in many human cancers (Kito et al., 2001; Raveh and Kimchi, 2001; Esteller and Herman, 2004; Subramaniam et al., 2009; Asada et al., 2013). These genes act in pathways of apoptosis, DNA repair and proliferative block, respectively, (Supic et al., 2011) and their inactivation can favor oncogenesis and progression of oral tumors (Towle and Garnis, 2012; D'Souza and Saranath, 2015). In addition, all three genes were confirmed by an epigenome-wide methylation analysis using dysplastic and OSCC tissues (Towle et al., 2013).

This study aimed to investigate the hypermethylation in DAPK, MGMT and RUNX3 promoter regions and their association with clinicopathological features and the prognostic overall survival and disease-free survival in HPV-negative OOSCC.

\section{Subjects and Methods}

\section{Ethical issues}

This research was approved by the research ethics committee of the Integrated Center for Health Care CIAS/Unimed Vitória (process number 318/2011). All patients were informed about the study and signed a written informed consent.

\section{Patients}

The participants were recruited at the Head and Neck Surgery Section, Hospital Santa Rita de Cassia, located in Vitoria, Espírito Santo, Brazil, between 2011 and 2017. To prevent the existence of HPV status bias, the inclusion criteria were patients with conclusive diagnosis of OOSCC HPV DNA negative, who were not submitted to any antitumoral therapy. HPV negative status was confirmed by polymerase chain reaction (PCR) using GP5+/6+, MY09/11 and PGMY09/11 primer sets (Erhart et al., 2016). Patients diagnosed with relapsed OOSCC were excluded as well as individuals with debilitating systemic conditions that limited their participation.

Clinical and pathological data (i.e., age, sex, tumour site, TNM stage, alcohol consumption and tobacco exposure) were obtained by interview and from the medical records. The tumor clinical stage was categorized as early $(0, \mathrm{I}$ and II) or advanced (III and IV) according to the TNM classification system (Wittekind et al., 2014). Patients were considered non-smokers or non-alcoholics when they claimed never to have had the habit of alcohol or tobacco consumption. Volunteers were considered smokers or alcoholics when they smoked or had smoked on average one cigarette, cigar or pipe regularly for at least one year and ingested or had ingested alcoholic beverage (regularly/frequently) in life, respectively. Patients were followed up until 24 months or until death and outcomes were classified as alive, deceased and relapse.

\section{DNA extraction, quantification and sodium bisulfite modification}

DNA was extracted from tumor samples stored at -80 ${ }^{\circ} \mathrm{C}$ originated of surgical resection. The used method was adapted from the phenol chloroform protocol from Goelz et al. (1985). DNA concentration was determined using NanoDrop 2000 (Thermo Fisher Scientific, Delaware, USA). DNA integrity was evaluated by human $\beta$-globin gene PCR. Using the methylSEQr Bisulfite Conversion kit (Applied Biosystems, Foster City, California, USA), $300 \mathrm{ng}$ of DNA from each sample were subjected to bisulfite conversion.

\section{Methylation Specific - Polymerase Chain Reaction (MS-PCR)}

Each gene was tested with two different primers pairs: unmethylated $(\mathrm{U})$ and methylated $(\mathrm{M})$ both with previously described sequences and showed in Table 1. The primer pair $\mathrm{U}$ was specific for unmethylated alleles, rich in uracils, and 
Table 1 - Primer sequences, annealing temperature and size of MS-PCR amplicons used for DAPK, MGMT and RUNX3 genes.

\begin{tabular}{|c|c|c|c|c|c|}
\hline Gene & Allele & Sequence $\left(5^{\prime}-3^{\prime}\right)$ & $\mathrm{AT}^{\mathrm{A}}$ & Amplicon size in base pair & Reference \\
\hline$D A P K$ & $\mathrm{U}^{\mathrm{B}}$ & $\begin{array}{c}\mathrm{F}^{\mathrm{D}}: \text { GGAGGATAGTTGGATTGAGTTAATGTT } \\
\mathrm{R}^{\mathrm{E}} \text { : CAAATCCСТCССАAАCACCAA }\end{array}$ & $60^{\circ} \mathrm{C}$ & 106 & Katzenellenbogen et al., 1999 \\
\hline & $\mathrm{M}^{\mathrm{C}}$ & $\begin{array}{c}\mathrm{F}^{\mathrm{D}}: \text { GGATAGTCGGATGGAGTTAACGTC } \\
\mathrm{R}^{\mathrm{E}}: \text { CCCTCCCAAACGCCGA }\end{array}$ & & 98 & \\
\hline$M G M T$ & $\begin{array}{c}\mathrm{U}^{\mathrm{B}} \\
\mathrm{M}^{\mathrm{C}}\end{array}$ & $\begin{array}{c}\mathrm{F}^{\mathrm{D}}: \text { TTTGTGTTTTGATGTTTGTAGGTTTTTGT } \\
\mathrm{R}^{\mathrm{E}} \text { : AACTCCACACTCTTCCAAAAACAAAACA } \\
\mathrm{F}^{\mathrm{D}}: \text { TTTCGACGTTCGTAGGTTTTCGC } \\
\mathrm{R}^{\mathrm{E}} \text { : GCACTCTTCCGAAAACGAAACG }\end{array}$ & $55^{\circ} \mathrm{C}$ & 93 & Esteller et al., 1999 \\
\hline$R U N X 3$ & $\mathrm{M}^{\mathrm{C}}$ & $\begin{array}{c}\mathrm{F}^{\mathrm{D}}: \text { AAGTGGGAAAGTAGAAGTGGTG } \\
\mathrm{R}^{\mathrm{E}}: \text { CCAAACAAACTACAAACAACCA } \\
\mathrm{F}^{\mathrm{D}}: \text { TATTCGTTAGGGTTCGTTCGT } \\
\mathrm{R}^{\mathrm{E}}: \text { AAACAACCACGAAAAACGAC }\end{array}$ & $62{ }^{\circ} \mathrm{C}$ & 125 & Kim et al., 2004 \\
\hline
\end{tabular}

Abbreviations: A: annealing temperature; B: unmethylated; C: methylated; D: forward primer; E: reverse primer.

the $\mathrm{M}$ primers were specific for methylated regions whose cytokines remain unchanged.

Normal lymphocyte DNA methylated in vitro by the CpG Methyltransferase enzyme (M.SssI) (Thermo Fisher Scientific) was used as reference control of hypermethylated sequence. This sample was used as positive amplification control for $\mathrm{M}$ primers and negative control for U primers. DNA from normal lymphocytes was used as reference for unmethylated sequences, serving as positive control for $\mathrm{U}$ primers and negative control for $\mathrm{M}$ primers. Both controls have been modified by bisulfite as described.

The PCR reaction mixture consisted of $2 \mu \mathrm{l}$ of modified DNA, $0.072 \mathrm{mM}$ of each dinucleotide triphosphate (Invitrogen/Life Technologies, California, USA), 1X of PCR buffer ( $50 \mathrm{mM} \mathrm{KCl}, 20 \mathrm{mM}$ Tris- $\mathrm{HCl} \mathrm{pH} 8.4$ ) of the Platinum Taq DNA Polymerase (Invitrogen), $0.54 \mathrm{mM}$ of $\mathrm{MgCl}_{2}$ (Invitrogen), $0.9 \mathrm{U}$ of Platinum Taq DNA Polymerase (Invitrogen) and $0.6 \mu \mathrm{M}$ of each primer (Invitrogen).

Fragments were amplified in a Veriti 96-Well Thermal Cycler (Applied Biosystems) under the following conditions: initial denaturation at $95^{\circ} \mathrm{C}$ for $2 \mathrm{~min}$; $35-38$ cycles consisting of denaturation at $95{ }^{\circ} \mathrm{C}$ for $30 \mathrm{~s}$; annealing at a specific temperature (AT) for $30 \mathrm{sec}$ and extension $72^{\circ} \mathrm{C}$ for $30 \mathrm{~s}$; final extension of $10 \mathrm{~min}$ at $72^{\circ} \mathrm{C}$. The MS-PCR conditions are shown in Table 1 . The MS-PCR products were subjected to electrophoresis on $7 \%$ polyacrylamide gel stained with silver nitrate.

\section{Statistical analysis}

Statistical analysis was performed with SPSS Statistics v20.0 (SPSS Incorporation, Chicago). The association between variables was tested by Chi-Square test or Fisher's exact test. All variables with a p-value $<0.25$ in association tests were subjected to multiple logistic regression analysis. The overall survival and disease-free survival were estimated and compared using the Kaplan-Meier method and log-rank tests, respectively. Multivariate Cox regression analysis was performed to verify if there was any association between the variables when evaluated together by the same model. Associations were considered significant when $\mathrm{p}<$ 0.05 .

\section{Results}

\section{Patients}

Seventy-two patients were included in the study. The mean age was 57.25 , ranging from 31 to 84 years old. Alcoholism was reported by $60.86 \%$ (42/69) and smoking was assumed by $62.31 \%$ (43/69). Those who claimed not to use any of these substances amounted to $21.73 \%(15 / 69)$. Most patients $(69.44 \%$; 50/72) were at advanced stages of the disease (III and IV), with tumors T3 and T4 accounting for $55.55 \%(40 / 72)$ of samples. One patient had distant metastasis. Follow-up data were obtained for $81.94 \%$ (59/72) of the patients. During this period, $13.56 \%(8 / 59)$ of the patients developed recurrence, and 35.59\% (21/59) died. The clinicopathological description of patients is shown in Table 2.

\section{Methylation profile of DAPK, MGMT and RUNX3}

Hypermethylation was found in $38.88 \%$ (28/72) of the tumors for $D A P K$ and $19.44 \%$ (14/72) for $M G M T$. Hypermethylation in at least one of the genes was found in $48.61 \% \quad(35 / 72)$ of the cases. Simultaneous hypermethylation for $D A P K$ and $M G M T$ reached $9.72 \%$ (7/72). Hypermethylation at RUNX3 was observed in one sample $(1.38 \%)$ which presented all genes hypermethylated. 
Reis et al.

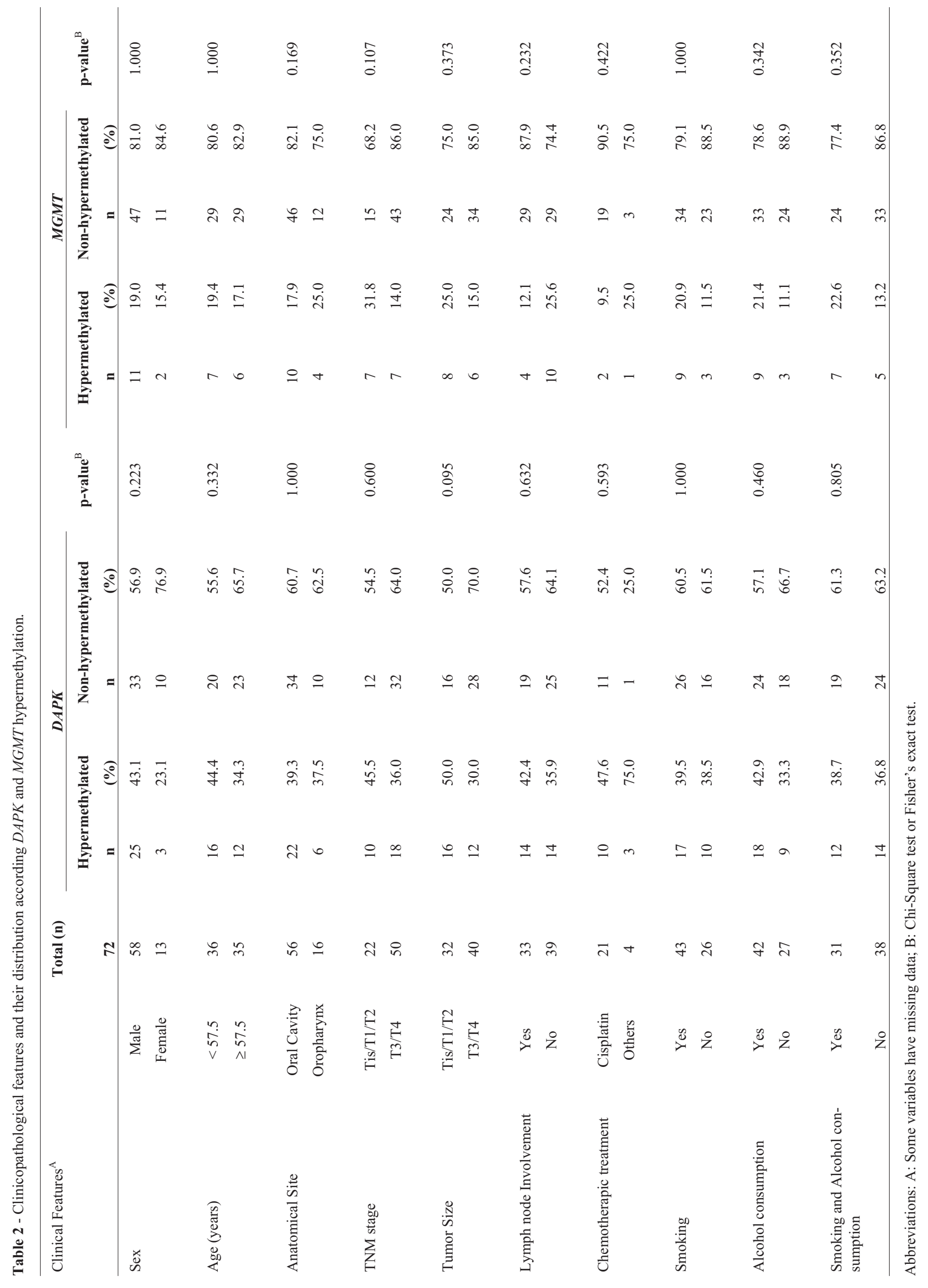




\section{Clinicopathological features and hypermethylation of $D A P K$ and MGMT genes}

The patients' clinicopathological description according to hypermethylation of $D A P K$ and $M G M T$ genes is summarized in Table 2 . There were no statistically significant results in the association tests between hypermethylation results and the following clinicopathological data: age, sex, smoking and alcohol addiction anatomical site, tumor stage, tumor size, lymph node involvement and chemotherapic treatment. Variables that presented $p<0.25$ in association analyses were used in a multiple logistic regression analysis. As shown in Table 3, we observed that individuals with initial tumor size (Tis, $\mathrm{T} 1$ and $\mathrm{T} 2)$ were 3.35 times $(95 \% \mathrm{CI}$ 1.093 - 10.329) more likely to have methylation of the $D A P K$ gene than those who did not. The Hosmer-Lemersshow test demonstrated that the regression model was adequate $(p=0.384)$. None of the other independent variables analyzed were shown to predict gene methylation events. Analyses were not performed for RUNX3.

\section{Overall survival (OS) and Disease free survival (DFS)}

In OS and DFS evaluation, the 2-year survival was analyzed according to $D A P K$ and $M G M T$ methylation status, clinical staging and tumor size $(\mathrm{T})$ and lymph node metastasis $(\mathrm{N})$.

As shown in Figure 1, patients with hypermethylation of $M G M T$ gene had better overall survival $(\mathrm{p}=0.008)$ than patients without. All patients with hypermethylation of
$M G M T$ remained alive until the end of the follow-up, while approximately $50 \%$ of patients without hypermethylation remained alive until the end of the follow-up, as seen in Figure 1. Patients in early staging $(0$, I and II; $p<0.001)$ and with smaller tumors (T1 and T2; $<0.001)$ had better survival. All patients in early staging remained alive until the end of the follow-up while more than $60 \%$ of patients with larger tumors died during follow-up.

The multivariate Cox regression analysis was performed in order to confirm whether the hypermethylation of the evaluated genes and the prognostic factors (tumor size and lymph node metastasis) showed any association when evaluated together in the same model. As observed in Table 4 , the multivariate regression showed that tumor size showed an association with survival $(\mathrm{p}=0.001)$. Therefore, we can infer that patients with advanced tumors have 13.42 times the risk of death.

\section{Discussion}

Hypermethylation of $\mathrm{CpG}$ islands in genes related to cancer has been considered an important event in OOSCC evolution. We have evaluated the methylation status of the $D A P K, M G M T$ and RUNX3 genes in 72 OOSCC HPV negative tumors. Among these genes, hypermethylation in the $M G M T$ gene correlates with better overall survival.

Promoter hypermethylation rates found in our study fit on intervals reported in the HNSCC literature for DAPK (12 -71.69\%) (Li et al., 2013; Noorlag et al., 2014) and MGMT (18.1-58.67\%) (Zuo et al., 2004; Strzelczyk et al., 2018),

Table 3 - Multiple logistic regression of clinical features and $D A P K$ and $M G M T$ hypermethylation.

\begin{tabular}{|c|c|c|c|c|}
\hline \multirow[t]{2}{*}{ Clinical Features $^{\mathrm{A}}$} & & \multicolumn{3}{|c|}{$D A P K$} \\
\hline & & OR (Adjusted) ${ }^{\mathrm{B}}$ & $95 \% \mathrm{CI}^{\mathrm{C}}$ & $\mathrm{p}$-value ${ }^{\mathrm{D}}$ \\
\hline \multirow[t]{2}{*}{ Sex } & Male & $1^{\mathrm{E}}$ & $0.588-10.607$ & 0.215 \\
\hline & Female & 2.497 & & \\
\hline \multirow[t]{2}{*}{ Tumor Size } & Tis/T1/T2 & 3.359 & $1.093-10.329$ & 0.034 \\
\hline & $\mathrm{T} 3 / \mathrm{T} 4$ & $1^{\mathrm{E}}$ & & \\
\hline \multirow[t]{2}{*}{ Lymph node Involvement } & Yes & 1.874 & $0.608-5.779$ & 0.274 \\
\hline & No & $1^{\mathrm{E}}$ & & \\
\hline \multirow[t]{2}{*}{ Clinical Features } & & \multicolumn{3}{|c|}{$M G M T$} \\
\hline & & OR (Adjusted) ${ }^{\mathrm{B}}$ & $95 \% \mathrm{CI}^{\mathrm{C}}$ & p-value ${ }^{D}$ \\
\hline \multirow[t]{2}{*}{ Anatomical Site } & Oral Cavity & $1^{\mathrm{E}}$ & $0.563-41.066$ & 0.151 \\
\hline & Oropharynx & 4.809 & & \\
\hline \multirow[t]{2}{*}{ Tumor Size } & Tis/T1/T2 & 1.663 & $0.441-6.275$ & 0.453 \\
\hline & $\mathrm{T} 3 / \mathrm{T} 4$ & $1^{\mathrm{E}}$ & & \\
\hline \multirow[t]{2}{*}{ Lymph node Involvement } & Yes & 0.503 & $0.123-2.051$ & 0.338 \\
\hline & No & $1^{\mathrm{E}}$ & & \\
\hline
\end{tabular}

Abbreviations: A: Some variables have missing data; B: Odds Ratio; C: Confidence Interval; D: Multiple logistic regression (Adjusted to all variables); E: Reference category. 

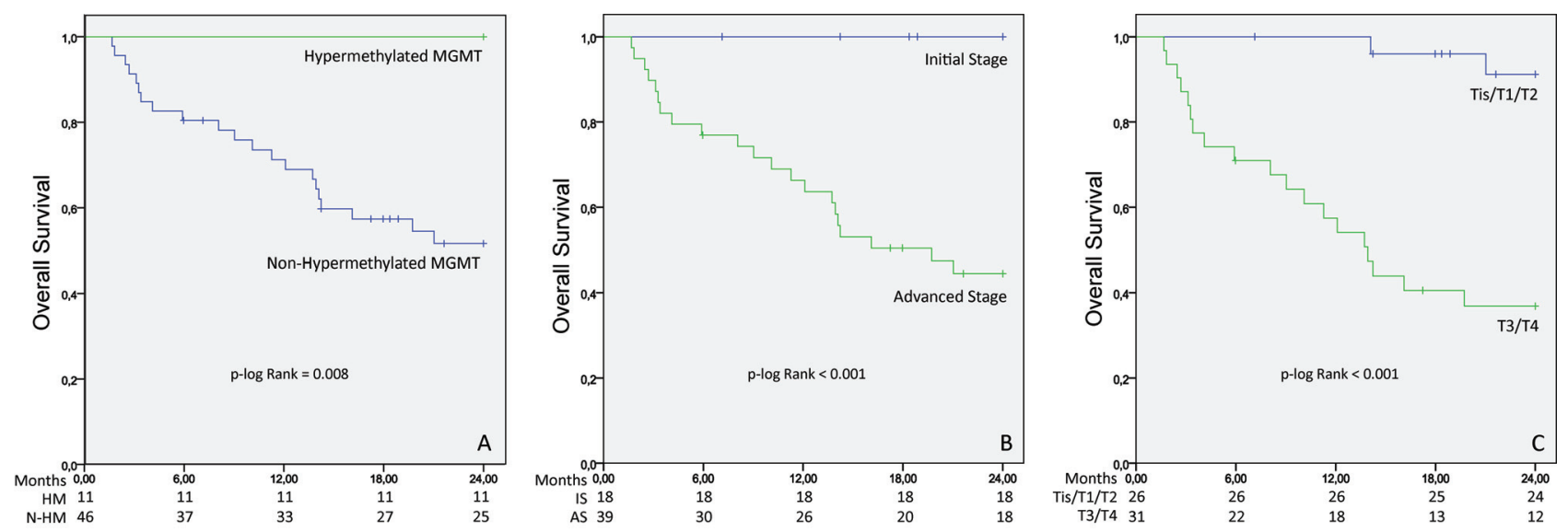

Figure 1 - Kaplan Meier estimates of overall survival among patients with oral and oropharyngeal squamous cell carcinoma according to $M G M T$ hypermethylation, Tumor Stage and Tumor Size.

Abbreviations: A: MGMT hypermethylation; B: Tumor Stage; C: Tumor Size; HM: Hypermethylated; N-HM: Non-Hypermethylated; IS: Initial Stage; AS - Advanced Stage.

Table 4 - Multivariate Cox regression analysis of prognostic features and $D A P K$ and $M G M T$ hypermethylation.

\begin{tabular}{llll}
\hline Variables & $\mathrm{HR}^{\mathrm{A}}$ & $95 \% \mathrm{CI}$ for $\mathrm{HR}^{\mathrm{B}}$ & $\mathrm{p}$-value \\
\hline DAPK & 0.71 & $0.28-1.83$ & 0.476 \\
MGMT & $6.60 \mathrm{E}+05$ & $1.44 \mathrm{E}-259-$ & 0.966 \\
& & $3.02 \mathrm{E}+270$ & \\
Tumor Size & 13.42 & $2.88-62.52$ & $\mathbf{0 . 0 0 1}$ \\
$\begin{array}{l}\text { Lymph node In- } \\
\text { volvement }\end{array}$ & 1.01 & $0.42-2.45$ & 0.984 \\
\hline
\end{tabular}

Abbreviations: A: Hazard Ratio; B: Confidence Interval; C: Multivariate cox regression

but not for RUNX3 (15 - 70\%) (Gao et al., 2009; Zhang et al., 2013).

Multiple logistic regression analysis alone demonstrated a significant association between individuals with initial tumor size and methylation of the DAPK gene; $M G M T$ hypermethylation data were not associated with clinicopathological parameters in our study. In the studies of Martone et al. (2007), Steinmann et al. (2009), Rettori et al. (2013) and Misawa et al. (2016) associations were not observed between the status of the MGMT and DAPK genes and tumoral and clinical parameters.

$M G M T$ encodes an adduct repair enzyme of $\mathrm{O}^{6}$-methylguanine generated by the interaction of DNA with alkylating agents present, for example, in cigarette smoke (Christmann and Kaina, 2012). The MGMT promoter methylation can reduce the protein expression having therefore oncogenic potential (Cai et al., 2016). Although our report is not the first to point out the prognostic value of $M G M T$ for HNSCC patients, there is no consensus among studies previously published. Taioli et al. (2009) and Zuo et al. (2004) found an inverse relationship between hypermethylation and OS in samples of OOSCC and HNSCC, respectively. Whereas Dikshit et al. (2007), studying laryngeal and hypopharyngeal tumors, and Strzelczyk et al. (2018), working with oral cavity cancer, found no associ- ation with survival. Despite differences in etiology and behavior, our results of improved OS associated to $M G M T$ hypermethylation better fit in the conclusions of Chen et al. (2015). In their cohort of cisplatin-treated nasopharyngeal cancer patients, worse OS was observed for those with high $M G M T$ expression associated with absence of hypermethylation.

Cisplatin and the others platinum-containing anti-cancer drugs are widely used in the treatment of locally advanced HNSCC tumors (Schmitz et al., 2014). It acts as an alkylating agent leading to formation of platinum-DNA adducts blocking cell cycle and resulting in cancer cell apoptosis (Dasari and Tchounwou, 2014). Although cisplatin is not an $\mathrm{O}^{6}$-alkylguanine alkylating agent, its DNA damage is actively removed by $M G M T$ repair protein, as demonstrated by Chen et al. (2015). Thus, MGMT hypermethylation, and its consequent loss of expression, could be a prognostic biomarker for HNSCC patients candidates for cisplatin chemotherapy, predicting the chances of drug resistance. Since most patients begin treatment at later stages, the therapeutic approach may be more effective when oriented by the molecular tumor profile. It has been shown that MGMT promoter methylation is a good prognostic factor for patients with glioma treated with temozolomide, another alkylating drug (Pandith et al., 2018). In our study, however, there was no statistically significant relationship between the use of cisplatin and methylation of MGMT gene. This may be due to the small number of samples. Furthermore, the disagreement about survival results among the studies already published may be related to anatomical site differences, HPV status and patient's clinical stage.

In relation to TSG $D A P K$, preview studies reveal that its hypermethylation is a common phenomenon in HNSCC (Kulkarni and Saranath, 2004; Li et al., 2013; Misawa et al., 2016). It is known that $D A P K$, which is a mediator of cell death of interferon-gamma (INF- $\gamma$ )-induced apoptosis (Cai et al., 2017), is essential for activation of various cell death mechanisms, caspase dependent or not, and the p19ARF/p53 
signaling pathway, a classic pathway in cell cycle control (Bialik and Kimchi, 2004). Since death pathways abolition is critical for tumor growth, $D A P K$ hypermethylation may be suggestive of a higher malignant potential. This was correlated with lymph node involvement in studies of Sanchez-Cespedes et al. (2000) and Wong et al. (2011). Considering that epigenetic regulation is an early event in oral carcinogenesis (D'Souza and Saranath, 2015), its detection in normal tissue adjacent to the tumor (Kulkarni and Saranath, 2004; Wong et al., 2011), pre-cancerous lesions (Liu et al., 2012), and surgical margins (Martone et al., 2007) could contribute to the monitoring of tumor progression and clinical management in view of both over- and under treatment has an impact on patient morbidity (Shridhar $e t$ al., 2016). In this study, the multiple regression analysis demonstrated that tumors with sizes considered initial (Tis, $\mathrm{T} 1$ and T2), had a greater chance of being $D A P K$ methylated. The detection of early epigenetic events indicative of malignant potential can favor the diagnosis in early stages $(0, \mathrm{I}$ and II) and in the discovery of still small lesions (T1 e T2) (D'Souza and Saranath, 2015). As evidenced in this and other studies, it is known that these last two factors are indicative of good prognosis.

The low rate of hypermethylation found for $R U N X 3$ in this study (1.38\%) questions its importance in HNSCC genesis and development. $R U N X 3$ is commonly presented as an effector of the transforming growth factor beta (TGF- $\beta$ ) pathway known for its effects of inhibiting growth and promoting apoptosis (Bae and Choi, 2004). Recently, studies with HNSCC have suggested an oncogenic role of RUNX3. Tsunematsu et al. (2009) and Kudo et al. (2011) argue that in healthy oral mucosa this gene would be epigenetically silenced, since its expression would only be required during embryonic development. During carcinogenesis, its oncogenic action would be triggered by the demethylation of its $\mathrm{CpG}$ island, favoring cell growth and inhibition of apoptosis. It is possible that this gene has a dual performance in the development of the HNSCC, which could help in understanding the apparent inconsistencies between the results of this research with others in the literature. According to Lebrun (2012), the TGF- $\beta$ pathway may exhibit tumor suppressor action in the early stages and promotes invasion and metastasis in later stages. It is worth noting that even in studies in which hypermethylation was detected (Supic et al., 2011; Cordeiro-Silva et al., 2012), a relevant portion of the samples $(75 \%$ and $83 \%$, respectively) did not present hypermethylation, suggesting that $R U N X 3$ may be expressed.

$D A P K, M G M T$ and RUNX3 are TSGs whose hypermethylation has been reported as an important event in HNSCC. In the present study with HPV-negative oral and oropharynx tumors, only DAPK and MGMT showed consistent evidence of their potential as epigenetic markers, with considerable levels of hypermethylation in cancer cells and, for $M G M T$, prognostic relevance. These results could contribute to improve strategies in early diagnosis and follow-up guided by evaluation of gene methylation patterns. How- ever, it is important to highlight the need of further studies and clinical trials to define, for each subtype of HNSCC tumor, the actual diagnostic and predictive value of $D A P K$ and $M G M T$ as well as its viability and efficacy in clinical management.

\section{Acknowledgments}

This work was mainly financed by Fundação de Amparo à Pesquisa do Espírito Santo (FAPES) (053/13). This study was financed in part by the Coordenação de Aperfeiçoamento de Pessoal de Nível Superior - Brasil (CAPES) - Finance Code 001. Raquel Silva dos Reis was supported by Conselho Nacional de Desenvolvimento Científico e Tecnológico - CNPq (ref. 134008/2013-8). We are grateful to Head and Neck Surgery Group - Hospital Santa Rita de Cassia and to all the sample donors. We also thank the team from Laboratório Multiusuário de Análises Biomoleculares (LABIOM) (http://labiom.ufes.br/) for their support during DNA analyses.

\section{Conflict of Interest}

The authors declare that there is no conflict of interest that could be perceived as prejudicial to the impartiality of the reported research.

\section{Author Contributions}

RSR conducted the experiments, analyzed the data and wrote the manuscript, JAS conducted the experiments, PMA conducted the experiments, RSD analyzed the data, EVWS analyzed the data and wrote the manuscript, ES analyzed the data, LPA conducted the experiments, QSA conducted the experiments, LNRA wrote the manuscript, IBV conducted the experiments, MAL conducted the experiments, EDS conceived and the study, JRVP conceived and the study, SVvonZ conceived and the study and analyzed the data, MFC-S conceived and the study, IDL conceived and the study and analyzed the data. All authors read and approved the final version.

\section{References}

Asada K, Watanabe N, Nakamura Y, Ohira M, Westermann F, Schwab M, Nakagawara A and Ushijima T (2013) Stronger prognostic power of the $\mathrm{CpG}$ island methylator phenotype than methylation of individual genes in neuroblastomas. Jpn J Clin Oncol 43:641-645.

Bae SC and Choi JK (2004) Tumor suppressor activity of RUNX3. Oncogene 23:4336-4340.

Bialik S and Kimchi A (2004) DAP-kinase as a target for drug design in cancer and diseases associated with accelerated cell death. Semin Cancer Biol 14:283-294.

Byakodi R, Byakodi S, Hiremath S, Byakodi J, Adaki S, Marathe K and Mahind P (2012) Oral cancer in India: an epidemiologic and clinical review. J Community Health 37:316-319.

Cai F, Xiao X, Niu X, Shi H and Zhong Y (2016) Aberrant methylation of MGMT promoter in HNSCC: a meta-analysis. PLoS One 11:e0163534. 
Cai F, Xiao X, Niu X and Zhong Y (2017) Association between promoter methylation of DAPK gene and HNSCC: a meta-analysis. PLoS One 12: e0173194.

Carvalho AL, Henrique R, Jeronimo C, Nayak CS, Reddy AN, Hoque MO, Chang S, Brait M, Jiang WW, Kim MM et al. (2011) Detection of promoter hypermethylation in salivary rinses as a biomarker for head and neck squamous cell carcinoma surveillance. Clin Cancer Res 17:4782-4789.

Castilho RM, Squarize CH and Almeida LO (2017) Epigenetic modifications and head and neck cancer: implications for tumor progression and resistance to therapy. Int J Mol Sci 18:E1506.

Chen SH, Kuo CC, Li CF, Cheung CH, Tsou TC, Chiang HC, Yang YN, Chang SL, Lin LC, Pan HY et al. (2015) O6-methylguanine DNA methyltransferase repairs platinum-DNA adducts following cisplatin treatment and predicts prognoses of nasopharyngeal carcinoma. Int $\mathrm{J}$ Cancer 137:1291-1305.

Christmann M and Kaina B (2012) O6-methylguanine-DNA methyltransferase (MGMT): impact on cancer risk in response to tobacco smoke. Mutat Res 736:64-74.

Colacino JA, Dolinoy DC, Duffy SA, Sartor MA, Chepeha DB, Bradford CR, McHugh JB, Patel DA, Virani S and Walline HM (2013) Comprehensive analysis of DNA methylation in head and neck squamous cell carcinoma indicates differences by survival and clinicopathologic characteristics. PLoS One 8:e54742.

Dahiya K and Dhankhar R (2016) Updated overview of current biomarkers in head and neck carcinoma. World J Methodol 6:77-86.

Dasari S and Tchounwou PB (2014) Cisplatin in cancer therapy: molecular mechanisms of action. Eur J Pharmacol 740:364-378.

Cordeiro-Silva MF, Stur E, Agostini LP, Podestá JR, Oliveira JC, Soares MS, Mendonça EF, Gouvea SA, Von Zeidler SV and Louro ID (2012) Promoter hypermethylation in primary squamous cell carcinoma of the oral cavity and oropharynx: a study of a Brazilian cohort. Mol Biol Rep 39:10111-10119.

Dikshit RP, Gillio-Tos A, Brennan P, De Marco L, Fiano V, Martinez-Peñuela JM, Boffetta $P$ and Merletti F (2007) Hypermethylation, risk factors, clinical characteristics, and survival in 235 patients with laryngeal and hypopharyngeal cancers. Cancer 110:1745-1751.

D'Souza W and Saranath D (2015) Clinical implications of epigenetic regulation in oral cancer. Oral Oncol 51:1061-1068.

Erhart SM, Rivero ER, Bazzo ML and Onofre AS (2016) Comparative evaluation of the GP5 +/6 +, MY09/11 and PGMY09/11 primer sets for HPV detection by PCR in oral squamous cell carcinomas. Exp Mol Pathol 100:13-16.

Esteller M and Herman JG (2004) Generating mutations but providing chemosensitivity: the role of O6-methylguanine DNA methyltransferase in human cancer. Oncogene 23:1-8.

Esteller M, Hamilton SR, Burger PC, Baylin SB and Herman JG (1999) Inactivation of the DNA repair gene O6-methylguanine-DNA methyltransferase by promoter hypermethylation is a common event in primary human neoplasia. Cancer Res 59:793-797.

Gao F, Huang C, Lin M, Wang Z, Shen J, Zhang H, Jiang L and Chen Q (2009) Frequent inactivation of RUNX3 by promoter hypermethylation and protein mislocalization in oral squamous cell carcinomas. J Cancer Res Clin Oncol 135:739-747.

Goelz SE, Hamilton SR and Vogelstein B (1985) Purifications of DNA from formaldehyde fixed and paraffin embedded tissue. Biochem Biophys Res Commun 130:118-126.
Gupta B, Johnson NW and Kumar N (2016) Global epidemiology of head and neck cancers: a continuing challenge. Oncology 91:13-23.

Hermanek P, Hutter RVP, Sobin LH, Wagner G and Wittekind C (1997) TNM Atlas: illustrated guide to the TNM/pTNM classification of malignant tumors. 4th edition. Springer-Verlag Berlin Heidelberg, Berlin, 343p.

Hussein AA, Helder MN, Visscher JG, Leemans CR, Braakhuis BJ, Vet HCW and Forouzanfar T (2017) Global incidence of oral and oropharynx cancer in patients younger than 45 years versus older patients: a systematic review. Eur J Cancer 82:115-127.

Jemal A, Siegel R, Ward E, Hao Y, Xu J, Murray T and Thun MJ (2008a) Cancer statistics, 2008. CA Cancer J Clin 58:71-96.

Jemal A, Thun MJ, Ries LA, Howe HL, Weir HK, Center MM, Ward E, Wu XC, Eheman C and Anderson R (2008b) Annual report to the nation on the status of cancer, 1975-2005, featuring trends in lung cancer, tobacco use, and tobacco control. J Natl Cancer Inst 100:1672-1694.

Katzenellenbogen RA, Baylin SB and Herman JG (1999) Hypermethylation of the DAP-kinase $\mathrm{CpG}$ island is a common alteration in B-cell malignancies. Blood 93:4347-4353.

Kim TY, Lee HJ, Hwang KS, Lee M, Kim JW, Bang YJ and Kang GH (2004) Methylation of RUNX3 in various types of human cancers and premalignant stages of gastric carcinoma. Lab Invest 84:479-484.

Kito H, Suzuki H, Ichikawa T, Sekita N, Kamiya N, Akakura K, Igarashi $\mathrm{T}$, Nakayama $\mathrm{T}$, Watanabe $\mathrm{M}$, Harigaya $\mathrm{K}$ et al. (2001) Hypermethylation of the CD44 gene is associated with progression and metastasis of human prostate cancer. Prostate 49:110-115.

Koutsimpelas D, Pongsapich W, Heinrich U, Mann S, Mann WJ and Brieger J (2012) Promoter methylation of MGMT, MLH1 and RASSF1A tumor suppressor genes in head and neck squamous cell carcinoma: pharmacological genome demethylation reduces proliferation of head and neck squamous carcinoma cells. Oncol Rep 27:1135-1141.

Kudo Y, Tsunematsu T and Takata T (2011) Oncogenic role of RUNX3 in head and neck cancer. $\mathrm{J}$ Cell Biochem 112:387-393.

Kulkarni V and Saranath D (2004) Concurrent hypermethylation of multiple regulatory genes in chewing tobacco associated oral squamous cell carcinomas and adjacent normal tissues. Oral Oncol 40:145-153.

Lebrun JJ (2012) The dual role of TGF $\beta$ in human cancer: from tumor suppression to cancer metastasis. ISRN Mol Biol 2012:381428.

Lechner M, Fenton T, West J, Wilson G, Feber A, Henderson S, Thirlwell C, Dibra HK, Jay A, Butcher L et al. (2013) Identification and functional validation of HPV-mediated hypermethylation in head and neck squamous cell carcinoma. Genome Med 5:15.

Li C, Wang L, Su J, Zhang R, Fu L and Zhou Y (2013) mRNA expression and hypermethylation of tumor suppressor genes apoptosis protease activating factor- 1 and death-associated protein kinase in oral squamous cell carcinoma. Oncol Lett 6:280-286.

Liu Y, Zhou ZT, He QB and Jiang WW (2012) DAPK promoter hypermethylation in tissues and body fluids of oral precancer patients. Med Oncol 29:729-733.

Mao L, Hong WK and Papadimitrakopoulou VA (2004) Focus on head and neck cancer. Cancer Cell 5:311-316.

Martone T, Gillio-Tos A, De Marco L, Fiano V, Maule M, Cavalot A, Garzaro M, Merletti F and Cortesina G (2007) Association between hypermethylated tumor and paired surgical margins 
in head and neck squamous cell carcinomas. Clin Cancer Res 13:5089-5094.

Misawa K, Mochizuki D, Imai A, Endo S, Mima M, Misawa Y, Kanazawa T, Carey TE and Mineta H (2016) Prognostic value of aberrant promoter hypermethylation of tumor-related genes in early-stage head and neck cancer. Oncotarget 7:26087-26098.

Miyazaki H, Patel V, Wang H, Edmunds RK, Gutkind JS and Yeudall WA (2006) Down-regulation of CXCL5 inhibits squamous carcinogenesis. Cancer Res 66:4279-4284.

Montebugnoli L, Gissi DB, Flamminio F, Gentile L, Dallera V, Leonardi E, Beccarini T and Foschini MP (2014) Clinicopathologic parameters related to recurrence and locoregional metastasis in 180 oral squamous cell carcinomas. Int J Surg Pathol 22:55-62.

Morandi L, Gissi D, Tarsitano A, Asioli S, Gabusi A, Marchetti C, Montebugnoli L and Foschini MP(2017) CpG location and methylation level are crucial factors for the early detection of oral squamous cell carcinoma in brushing samples using bisulfite sequencing of a 13-gene panel. Clin Epigenetics 9:85.

Noorlag R, van Kempen PM, Moelans CB, Jong R, Blok LE, Koole R, Grolman W, van Diest PJ, van Es RJ and Willems SM (2014) Promoter hypermethylation using 24-gene array in early head and neck cancer: better outcome in oral than in oropharyngeal cancer. Epigenetics 9:1220-1227.

Pai SI and Westra WH (2009) Molecular pathology of head and neck cancer: implications for diagnosis, prognosis, and treatment. Annu Rev Pathol 4:49-70.

Pandith AA, Qasim I, Zahoor W, Shah P, Bhat AR, Sanadhya D, Shah ZA and Naikoo NA (2018) Concordant association validates MGMT methylation and protein expression as favorable prognostic factors in glioma patients on alkylating chemotherapy (Temozolomide). Sci Rep 8:6704.

Polanska H, Raudenska M, Gumulec J, Sztalmachova M, Adam V, Kizek R and Masarik M (2014) Clinical significance of head and neck squamous cell cancer biomarkers. Oral Oncol 50:168-177.

Raveh T and Kimchi A (2001) DAP Kinase - a proapoptotic gene that functions as a tumor suppressor. Exp Cell Res 264:185-192.

Rettori MM, Carvalho AC, Longo AL, Oliveira CZ, Kowalski LP, Carvalho AL and Vettore AL (2013) TIMP3 and CCNA1 hypermethylation in HNSCC is associated with an increased incidence of second primary tumors. J Transl Med 11:316.

Sailer V, Holmes EE, Gevensleben H, Goltz D, Dröge F, Franzen A, Dietrich J, Kristiansen G, Bootz F, Schröck Aet al. (2017) PITX3 DNA methylation is an independent predictor of overall survival in patients with head and neck squamous cell carcinoma. Clin Epigenetics 9:12.

Sanchez-Cespedes M, Esteller M, Wu L, Nawroz-Danish H, Yoo GH, Koch WM, Jen J, Herman JG and Sidransky D (2000) Gene promoter hypermethylation in tumors and serum of head and neck cancer patients. Cancer Res 60:892-895.

Schmitz S, Ang KK, Vermorken J, Haddad R, Suarez C, Wolf GT, Hamoir M and Machiels JP (2014) Targeted therapies for squamous cell carcinoma of the head and neck: current knowledge and future directions. Cancer Treat Ver 40:390-404.

Shield KD, Ferlay J, Jemal A, Sankaranarayanan R, Chaturvedi AK, Bray F and Soerjomataram I (2017) The global incidence of lip, oral cavity, and pharyngeal cancers by subsite in 2012 . CA Cancer J Clin 67:51-64.

Shridhar K, Walia GK, Aggarwal A, Gulati S, Geetha AV, Prabhakaran D, Dhillon PK and Rajaraman P (2016) DNA methylation markers for oral pre-cancer progression: a critical review. Oral Oncol 53:1-9.

Steinmann K, Sandner A, Schagdarsurengin U and Dammann RH (2009) Frequent promoter hypermethylation of tumor-related genes in head and neck squamous cell carcinoma. Oncol Rep 22:1519-1526.

Strzelczyk JK, Krakowczyk L and Owczarek AJ (2018) Aberrant DNA methylation of the p16, APC, MGMT, TIMP3 and $\mathrm{CDH} 1$ gene promoters in tumours and the surgical margins of patients with oral cavity cancer. J Cancer 9:1896-1904.

Subramaniam MM, Chan JY, Yeoh KG, Quek T, Ito K and Salto-Tellez M (2009) Molecular pathology of RUNX3 in human carcinogenesis. Biochim Biophys Acta 1796:315-331.

Supic G, Kozomara R, Jovic N, Zeljic K and Magic Z (2011) Prognostic significance of tumor-related genes hypermethylation detected in cancer-free surgical margins of oral squamous cell carcinomas. Oral Oncol 47:702-708.

Taioli E, Ragin C, Wang XH, Chen J, Langevin SM, Brown AR, Gollin SM, Garte S and Sobol RW (2009) Recurrence in oral and pharyngeal cancer is associated with quantitative MGMT promoter methylation. BMC Cancer 9:354.

Towle R and Garnis C (2012) Methylation-mediated molecular dysregulation in clinical oral malignancy. J Oncol 2012:170172.

Towle R, Truong D, Hogg K, Robinson WP, Poh CF and Garnis C (2013) Global analysis of DNA methylation changes during progression of oral cancer. Oral Oncol 49: 1033-1042.

Tsunematsu T, Kudo Y, Iizuka S, Ogawa I, Fujita T, Kurihara H, Abiko Y and Takata T (2009) RUNX3 has an oncogenic role in head and neck cancer. PLoS One 4:e5892.

Wittekind C, Asamura H and Sobin LH (2014) TNM atlas: illustrated guide to the TNM classification of malignant tumours. 6th edition. John Wiley \& Sons, West Sussex, 408 p.

Wong YK, Lee LT and Liu CJ (2011) Hypermethylation of MGMT and DAPK gene promoters is associated with tumorigenesis and metastasis in oral squamous cell carcinoma. J Dent Sci 6:158-164.

Zhang S, Feng XL, Shi L, Gong CJ, He ZJ, Wu HJ and Ling TY (2013) Genome-wide analysis of DNA methylation in tongue squamous cell carcinoma. Oncol Rep 29:1819-1826.

Zuo C, Ai L, Ratliff P, Suen JY, Hanna E, Brent TP and Fan CY (2004) O6-methylguanine-DNA methyltransferase gene: epigenetic silencing and prognostic value in head and neck squamous cell carcinoma. Cancer Epidemiol Biomarkers Prev 13:967-975.

Associate Editor: Marcia Margis-Pinheiro

License information: This is an open-access article distributed under the terms of the Creative Commons Attribution License (type CC-BY), which permits unrestricted use, distribution and reproduction in any medium, provided the original article is properly cited. 